\title{
FAKTOR- FAKTOR YANG MEMPENGARUHI CASH HOLDING
}

\author{
Nita Astuti $^{1}$ Rida Ristiyana $^{2}$ Luthfi Nuraini $^{3}$ \\ Fakultas Ekonomi dan Bisnis \\ Universitas Islam Syekh-Yusuf \\ nita.astuti@uni.ac.id ${ }^{1}$,rristiyana@unis.ac.id²,luthfi@unis.ac.id ${ }^{3}$ \\ DOI: https://doi.org/10.33592/jeb.v26i1.624
}

\begin{abstract}
This study aims to determine the effect of cash conversion cycle (cc), sales growth ( $\mathrm{sg}$ ), firm size $(f s)$ and net working capital (nw) on cash holding (ch) on manufacturing companies listed on the stock exchange indonesia for the period 2017-2019. The sample method using purposive sampling in order to obtain 97 companies with observational data of $(n)=264$ with data analysis in this study uses multiple linear regression. Based on the results of the analysis concluded that partially the cash conversion cycle (cc) and net working capital (nw) variables significantly influence cash holding (ch), while the sales growth ( $\mathrm{sg})$ and firm size $(f s)$ variables have no significant effect on cash holding ( $\mathrm{ch})$. Based on the simultaneous cash conversion cycle (cc), sales growth ( $\mathrm{sg}$ ), firm size ( $f$ s) and net working capital (nw) affect cash holding (ch).
\end{abstract}

Keywords: Cash Holding, Cash Conversion Cycle, Sales Growth, Firm Size and Net Working Capital

\begin{abstract}
Abstrak
Penelitian ini bertujuan untuk mengetahui pengaruh siklus konversi kas, pertumbuhan penjualan, ukuran perusahaan dan modal kerja bersih terhadap kas ditangan pada perusahaan manufaktur yang terdaftar di bursa efek indonesia periode 2017-2019. Metode pemilihan sampel menggunakan purposive sampling, sehingga diperoleh 97 perusahaan dengan data pengamatan $(\mathrm{n})=$ 264 dengan analisis data menggunakan regresi linier berganda. Berdasarkan hasil analisis disimpulkan bahwa secara parsial variabel siklus konversi kas dan modal kerja bersih berpengaruh signifikan terhadap kas ditangan, sedangkan variabel pertumbuhan penjualan dan ukuran perusahaan tidak berpengaruh signifikan terhadap kas ditangan. Secara simultan siklus konversi kas, pertumbuhan penjualan, ukuran perusahaan dan modal kerja bersih berpengaruh terhadap kas ditangan.
\end{abstract}

Kata kunci: Kas ditangan, Siklus Konversi Kas, Pertumbuhan Penjualan, Ukuran Perusahaan Modal Kerja Bersih

\section{A. Pendahuluan}

Kas memiliki peranan penting dalam suatu perusahaan, kas dibutuhkan tidak hanya untuk membiayai kegiatan operasi tetapi juga investasi. Kas merupakan salah satu ukuran perusahaan yang digunakan untuk membayar tagihan secara tepat waktu karena sifatnya yang sangat likuid. Kas yang berada dalam suatu perusahaan dinamakan Cash Holding.

$$
\text { Gill and Shah }
$$
mengemukakan bahwa" Cash holding didefinisikan sebagai kas yang dimiliki perusahaan atau yang tersedia untuk investasi dalam aset fisik dan didistribusikan pada investor. Cash Holding sangat penting karena menyediakan likuiditas bagi perusahaan yaitu perusahaan dapat melunasi kewajiban yang dimilki perusahaan dalam keadaan krusial". 
Menurut Ridha et al., (2019) "cash holding yang optimal harus dijaga perusahaan agar tidak mengalami kelebihan atau kekurangan, dan harus disediakan dalam batas jumlah yang ditentukan perusahaan. Beberapa perusahaan di Indonesia masih tidak melakukan penyimpanan kas dalam jumlah yang besar sehingga masih banyak perusahaan yang memliki masalah likuiditas".Untuk menghasilkan kas harus memperhatikan lamanya proses penyelesaian cash conversion cycle.

Marfuah \& Zulhilmi (2015), "Cash Conversion Cycle adalah waktu yang dibutuhkan perusahaan mulai dari saat perusahaan mengeluarkan uang untuk membeli bahan baku sampai dengan perusahaan mengumpulkan uang dari penjualan barang jadi. Semakin pendek waktu yang diperlukan semakin baik bagi perusahaan, sebaliknya semakin panjang waktu yang diperlukan semakin banyak modal yang harus ditanamkan". Lain halnya dengan hasil penelitian Liadi dan Suryanawa (2018) yang menyatakan bahwa

cash conversion cycle tidak memiliki pengaruh terhadap cash holding.

Faktor-faktor yang tidak kalah penting hubungannya dengan cash holding adalah sales growth, karena untuk menciptakan penjualan, laba, perusahaan perlu membuat cadangan kas dan memastikan waktu siklusnya dan membuat arus kas positif secara agregat (Gill and Shah, 2011). Berbeda dengan Panalar \& Ekadjaja (2020) menyatakan bahwa sales growth tidak berdampak terhadap cash holding.

Faktor lainnya adalah Firm Size, yaitu besar kecilnya perusahaan yang dapat diukur pada nilai total aktiva perusahaan (Saputra, 2015). Gomes (2012), mengemukakan bahwa" Firm Size akan berpengaruh terhadap tingkat cash holding perusahaan karena perusahaan akan berusaha menjaga tingkat operasi dan investasinya". Perusahaan yang sangat besar mampu menjaga tingkat cash holding-nya dalam kapasitas besar, sehingga dapat dipergunakan untuk cadangan tak terduga (Liestyasih \& Wiagustini, 2017).

Faktor lain dari cash holding adalah Net Working Capital. Menurut Ross et al, (2015) "Net Working Capital adalah aset lancar dan kewajiban lancar yang dapat menghasilkan modal kerja positif saat aset lancar lebih besar dari kewajiban lancar". Menurut Najema \& Rusdayanti (2019)"Net Working Capital memiliki pengaruh pada kas perusahaan, hal ini menunjukkan bahwa nilai Net Working Capital tinggi maka kas yang dipegang juga tinggi, karena kas merupakan bagian dari Net Working Capital".

Penelitian ini menggunakan perusahaan manufaktur yang terdaftar di Bursa Efek Indonesia periode 2017-2019 sebagai populasi. Manufaktur dipilh karena cash holding merupakan cara penilaian atas likuiditas suatu perusahaan, dimana dalam perusahaan manufaktur memiliki siklus/cycle konversi kas yang sangat lama karena terdapat proses perubahan bahan baku menjadi bahan jadi. Dengan alasan inilah maka penulis menjadikan perusahaan manufaktur sebagai objek penelitian.

\section{Hipotesis}

$\mathrm{Ha}_{1}$ : Ada pengaruh Cash Conversion Cycle terhadap Cash Holding.

$\mathrm{Ha}_{2}$ : Ada pengaruh Sales Growth terhadap Cash Holding.

$\mathrm{Ha}_{3}$ : Ada pengaruh Firm Size terhadap Cash Holding.

$\mathrm{Ha}_{4}$ : Ada pengaruh Net Working Capital terhadap Cash Holding. 
$\mathrm{Ha}_{5}$ : Ada pengaruh Cash Conversion Cycle, Sales Growth, Firm Size, Net Working Capital secara bersama-sama terhadap Cash Holding.

\section{Kerangka Pemikiran}

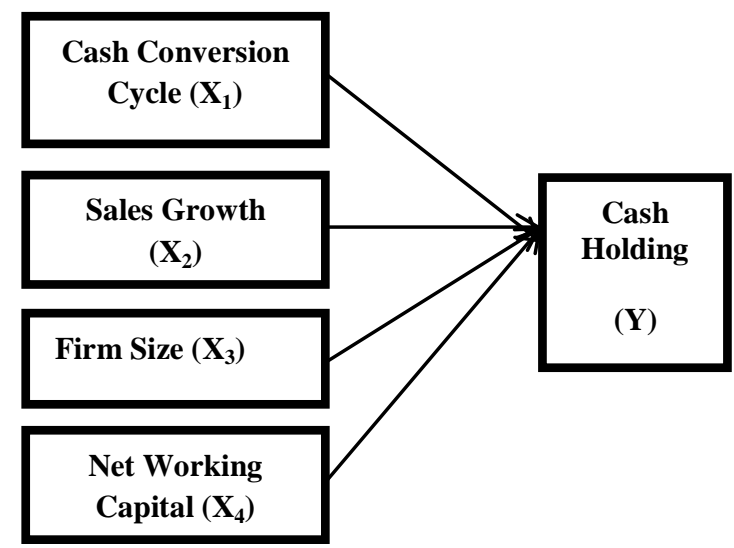

\section{Definisi Operasional Variabel:}

Proksi Variabel Cash Holding (Y) sebagai berikut (Marfuah \& Zulhilmi, 2015) :

Cah Holding $=\frac{\text { Kas dan Setara Kas }}{\text { Total Aset }}$

Proksi Variabel Cash Conversion Cycle (X1) sebagai berikut, (Keown, 2010) :

$\mathrm{CCC}=$ jumah hari piutang $(\mathrm{DSO})+$ jumlah hari penjualan pada persediaan (DSI) - jumlah hari pembayaran yang belum diselesaikan (DPO) ..(2)

Keterangan:

$$
\begin{aligned}
\text { DSO } & =\frac{\text { Piutang Dagang }}{\text { Penjualan } / 365} \\
\text { DSI } & =\frac{\text { Persediaan }}{\text { Harga Pokok penjualan } / 365}
\end{aligned}
$$$$
\mathrm{DPO}=\frac{\text { Hutang Dagang }}{\text { Harga pokok penjualan } / 365}
$$

Proksi Variabel Sales Growth (X2) sebagai berikut, (Oktamawati, 2017) :

$$
\text { Sales Growth }=\frac{\text { Penjualan } 1-\text { Penjualan } 0}{\text { Penjualan } 0}
$$

Proksi Variabel Firm Size (X3) sebagai berikut, (Gill \& Shah, 2011) :

$\mathrm{SIZ}=\mathrm{Ln}$ Total Assets

Proksi Variabel Net Working Capital (X4) sebagai berikut, (Sheikh et al., 2018) :

$N W C=\frac{\text { Current Asset }- \text { Current Liabilities }}{\text { Total Asset }}$

\section{B. Metode Penelitian}

Populasi penelitian ini adalah semua perusahaan manufaktur yang terdaftar di BEI periode 2017-2019 sebanyak 172 perusahaan. Dari populasi dipilih 97 perusahaan sebagai sampel dengan jumlah data pengamatan $(n)=264$ setelah dilakukan outlier. Metode pemilihan sampel menggunakan purposive sampling. Adapun kriteria pemilihan sampel adalah:

1. Perusahaan Manufaktur yang terdaftar di BEI selama periode 2017-2019.

2. Mempublikasikan Laporan Keuangan secara rutin selama periode 2017-2019.

3. Memiliki satuan mata uang Rupiah selama periode 2017-2019.

Penelitian ini menggunakan software SPSS versi 24,0. Tujuan penelitian ini adalah untuk menjawab hipotesis yang telah dibuat. Teknik analisis data yang digunakan adalah Statistik Deskriptif, Uji Normalitas, Uji Asumsi Klasik, Analisis Regresi linier berganda, dengan persamaan regresi digambarkan sebagai berikut :

$$
\mathrm{Y}=\mathrm{a}+\mathrm{b}_{1} \mathrm{CC}+\mathrm{b}_{2} \mathrm{SG}+\mathrm{b}_{3} \mathrm{FS}+\mathrm{b}_{4} \mathrm{NWC}+\mathrm{e}
$$

Dimana :

$$
\mathrm{Y}=\text { Cash Holding }
$$

$\mathrm{a}=$ Intercept (Konstanta)

b1 = Koefisien regresi untuk CC

b2 $=$ Koefisien regresi untuk SG

b3 = Koefisien regresi untuk FS 
b4 $=$ Koefisien regresi untuk NW

$\mathrm{CC}=$ Cash Holding

$\mathrm{SG}=$ Sales Growth

FS = Firm Size

$\mathrm{NWC}=$ Net Working Capital

\section{Hasil Penelitian dan Pembahasan}

\section{Statistik Deskriptif}

Statistik deskriptif menunjukkan data nilai mean, standar deviasi, maksimum dan minimum, disajikan pada tabel berikut:

Tabel 1. Hasil Statistik Deskriptif

\begin{tabular}{lrrrrr}
\hline \multicolumn{5}{c}{ Descriptive Statistics } \\
& $\mathrm{N}$ & Minimum & Maximum & \multicolumn{1}{c}{ Mean } & \multicolumn{1}{c}{ Std. Deviation } \\
\hline CH & 291 & .00 & .72 & .0967 & .12002 \\
CCC & 291 & -1219.17 & 530.17 & 123.9145 & 123.98851 \\
SG & 291 & -1.00 & 6.50 & .0773 & .43799 \\
FS & 291 & 17.74 & 37.51 & 28.1097 & 2.28121 \\
NWC & 291 & -1.06 & 1.27 & .2153 & .24801 \\
\hline
\end{tabular}

Pada Tabel 1 dapat dianalisis sebagai berikut :

1. Variabel Cash Holding mempunyai nilai rata-rata sebesar 0.0967 , nilai maksimum sebesar 0.72 nilai mininum sebesar 0.00 dan standar deviasi 0.12002 .

2. Variabel Cash Conversion Cycle mempunyai nilai rata-rata sebesar 123.9145, nilai maksimum sebesar 530.17 nilai minimum sebesar 1219.17 dan standar deviasi 123.98851 .

3. Variabel Sales Growth mempunyai nilai rata-rata sebesar 0.0773 , nilai maksimum sebesar 6.50 nilai minimum sebesar -1.00 dan standar deviasi 0.43799 .

4. Variabel Firm Size mempunyai nilai rata-rata sebesar 28.1097, nilai maksimum sebesar 37.51 nilai 
bahwa model regresi tidak mengalami masalah multikolinearitas.

\section{Uji Heteroskedastisitas}

Uji heteroskedastisitas pendeteksian dengan menggunakan scatter plot, disajikan dalam gambar berikut :

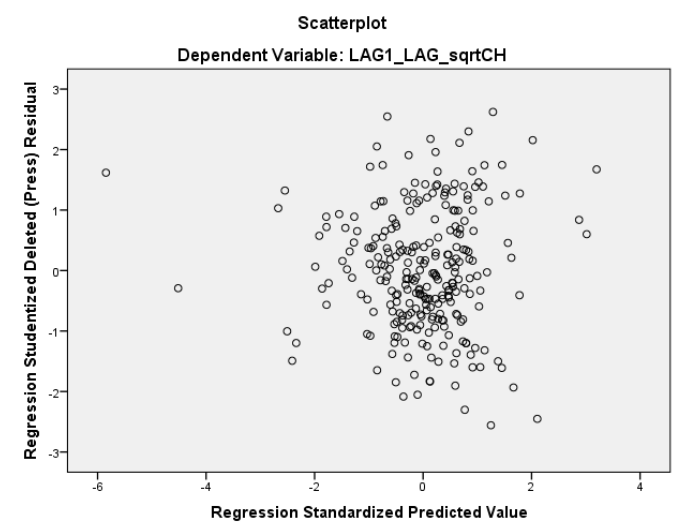

Gambar 1. Hasil Uji Heteroskedastisitas

Pada Gambar 1 bisa dilihat bahwa titiktitiknya menyebar tidak beraturan/secara acak. Dapat disimpulkan bahwa persamaan model regresi tidak mengalami masalah heteroskedastisitas.

\section{Uji Autokorelasi}

Uji autokorelasi menggunakan Durbin Watson, hasil semula terkena autokorelasi sehingga dilakukan pengobatan dengan menggunakan Cochrane Orcutt, yang disajikan paa tabel berikut :

\section{Tabel 4. Hasil Uji Autokorelasi}

\begin{tabular}{|c|c|c|c|c|c|}
\hline $\begin{array}{l}\text { Mod } \\
\text { el }\end{array}$ & $\mathrm{R}$ & $\begin{array}{c}\text { R } \\
\text { Squar } \\
\mathrm{e}\end{array}$ & $\begin{array}{c}\text { Adjuste } \\
\text { d R } \\
\text { Square }\end{array}$ & $\begin{array}{c}\text { Std. } \\
\text { Error of } \\
\text { the } \\
\text { Estimate }\end{array}$ & $\begin{array}{l}\text { Durbin- } \\
\text { Watson }\end{array}$ \\
\hline 1 & $.625^{\mathrm{a}}$ & .391 & .382 & .08709 & 1.992 \\
\hline
\end{tabular}

Pada Tabel 4 menunjukan bahwa nilai DW sebesar 1.992, diperoleh nilai $\mathrm{dL}=$ 1.77344 dan nilai $\mathrm{dU}=1.82010$. Karena nilai $\mathrm{DW}=1.992$ berada diatas $\mathrm{dL}=$ 1.7734, maka dapat disimpulkan tidak terjadi masalah autokorelasi.

\section{Uji Regresi Linier Berganda}

Hasil perhitungan regresi linier berganda dapat dilihat sebagai berikut :

Tabel 5. Hasil Uji Regresi Linier

\section{Berganda}

\begin{tabular}{lccccc}
\hline \multicolumn{7}{c}{$\begin{array}{c}\text { Unstandardized } \\
\text { Coefficients } \\
\text { Model }\end{array}$} & $\begin{array}{c}\text { Standardized } \\
\text { Coefficients }\end{array}$ & & \\
& B & Error & Beta & t & Sig. \\
\hline 1 (Constant) & -.051 & .047 & & & .278 \\
LAG1_LA & .018 & .002 & .394 & 7.530 & .000 \\
G_sqrtCCC & & & & & \\
LAG1_LA & .006 & .022 & .013 & .266 & .790 \\
G_SG & & & & & \\
LAG1_LA & -.003 & .003 & -.051 & -1.034 & .302 \\
G_FS & & & & & \\
LAG1_LA & .379 & .031 & .631 & 12.111 & .000 \\
G_NWC & & & & & \\
\hline
\end{tabular}

Pada Tabel 5 diperoleh persamaan regresi linier berganda sebagai berikut:

$$
\begin{gathered}
\mathrm{Y}=-\mathbf{0 . 0 5 1}+\mathbf{0 . 0 1 8} \mathrm{CC}+\mathbf{0 . 0 0 6} \mathrm{SG}-\mathbf{0 . 0 0 3} \\
\mathrm{FS}+\mathbf{0 . 3 7 9} \mathrm{NWC}+\mathrm{e}
\end{gathered}
$$

Yang dapat diuraikan sebagai berikut :

Konstanta $=-0.051$ menunjukan nilai negatif. Artinya variabel CC (Cash conversion cycle), SG (Sales growth), FS (Firm size) dan NWC (Net working (apital) $=0$, maka Cash Holding (Y) akan turun sebesar 0.051 .

1. Koefisien b1 $=0.018$ angka positif menandakan bahwa setiap peningkatan Cash Conversion Cycle (X1) 1 satuan dan (X) yang lain tetap, maka akan diikuti oleh peningkatan Cash Holding (Y) sebesar 0.018 .

2. Koefisien b2 $=0.006$ angka positif menandakan bahwa setiap peningkatan Sales Growth (X2) 1 satuan dan (X) yang lain tetap, maka akan diikuti oleh peningkatan Cash Holding (Y) sebesar 0.006 . 
3. Koefisien b3 $=-0.003$ angka negatif menandakan bahwa setiap peningkatan Firm Size (X3) 1 satuan dan (X) yang lain tetap, maka akan diikuti oleh penurunan Cash Holding (Y) sebesar 0.003 .

4. Koefisien b4 $=0.379$ angka positif menandakan bahwa setiap peningkatan Net working capital (X4) 1 satuan dan (X) yang lain tetap, maka akan diikuti oleh peningkatan Cash Holding (Y) sebesar 0.379 .

\section{Uji Hipotesis}

\section{a. Analisis Koefisien Determinasi (R2)}

Hasil pengolahan koefisien determinasi adalah sebagai berikut :

\section{Tabel 6. Hasil Uji Koefisien Determinasi}

\begin{tabular}{llrrr}
\hline & & & Adjusted R & \multicolumn{2}{c}{$\begin{array}{c}\text { Std. Error of } \\
\text { Model }\end{array}$} & R & R Square & \multicolumn{1}{c}{ Square } & the Estimate \\
\hline 1 & $.625^{\mathrm{a}}$ & .391 & .382 & .08709 \\
\hline
\end{tabular}

Pada Tabel 6 menunjukkan nilai Adjusted $\mathrm{R}$ Square sebesar 0.382. Ini berarti kontribusi yang diberikan oleh variabel independen (CCC, SG, FS, NWC) sebesar $38.2 \%$ dapat dijelaskan pengaruhnya terhadap variabel dependen $(\mathrm{CH})$, sisanya sebesar $61.8 \%$ dijelaskan oleh variabel lain yang mempengaruhi $\mathrm{Y}$.

\section{b. Uji parsial (Uji t)}

Hasil pengolahan uji t dalam penelitian ini adalah sebagai berikut :
Tabel 7. Hasil Uji t

\begin{tabular}{lcccccc}
\hline & \multicolumn{2}{c}{$\begin{array}{c}\text { Unstandardized } \\
\text { Coefficients } \\
\text { Model }\end{array}$} & $\begin{array}{c}\text { Standardized } \\
\text { Coefficients }\end{array}$ & & \\
& B & Error & Beta & t & Sig. \\
\hline 1 (Constant) & -.051 & .047 & & & .278 \\
LAG1_LA & .018 & .002 & .394 & 7.530 & .000 \\
G_sqrtCCC & & & & & \\
LAG1_LA & .006 & .022 & .013 & .266 & .790 \\
$\begin{array}{l}\text { G_SG } \\
\text { LAG1_LA }\end{array}$ & -.003 & .003 & -.051 & -1.034 & .302 \\
G_FS & & & & & & \\
LAG1_LA & .379 & .031 & .631 & 12.111 & .000 \\
G_NWC & & & & & \\
\hline
\end{tabular}

1. Hasil Uji-t H1 diperoleh angka t-hitung 7.53 dimana t-hitung lebih besar dari ttabel $(7.53>1.9690)$ dengan nilai signifikansi sebesar 0.000 . menunjukkan bahwa nilai signifikansi lebih kecil dari 0.05 sehingga dapat dikatakan Cash Conversion Cycle (X1) berpengaruh signifikan terhadap Cash Holding (Y) secara parsial.

2. Hasil Uji- $\mathrm{t} \mathrm{H} 2$ diperoleh angka thitung 0.266 dimana t-hitung lebih kecil dari t-tabel $(0.266<1.9690)$ dengan nilai signifikansi sebesar 0.790 , menunjukkan bahwa nilai signifikansi lebih besar dari 0.05 sehingga dapat dikatakan Sales Growth (X2) tidak berpengaruh signifikan terhadap Cash Holding (Y) secara parsial.

3. Hasil Uji-t H3 diperoleh angka thitung -1.034 dimana t-hitung lebih kecil dari t-tabel $(-1.034<1.9690)$ dengan nilai signifikansi sebesar 0.302 . menunjukkan bahwa nilai signifikansi lebih besar dari 0.05 sehingga dapat dikatakan Firm Size (X3) tidak berpengaruh signifikan terhadap Cash Holding (Y) secara parsial.

4. Hasil Uji-t H4 diperoleh angka t-hitung 12.111 dimana t-hitung lebih besar dari t-tabel $(12.111>1.9690)$ dengan nilai signifikansi sebesar 0.000 . menunjukkan bahwa nilai signifikansi lebih kecil dari 0.05 sehingga dapat dikatakan Net Working Capital (X4) 
berpengaruh signifikan terhadap Cash

Holding (Y) secara parsial.

\section{c. Uji Simultan (Uji F)}

Uji $\mathrm{F}$ untuk menguji pengaruh variabel CC, SG, FS dan NWC terhadap CH (Cash Holding) secara bersama-sama dapat dikatakan layak dengan tingkat signifikansi 0.05 atau $\mathrm{a}=5 \%$. Berikut data hasil pengolahan untuk uji $\mathrm{F}$ :

Tabel 8. Hasil Uji F

\begin{tabular}{|c|c|c|c|c|c|}
\hline Model & $\begin{array}{l}\text { Sum of } \\
\text { Squares }\end{array}$ & df & $\begin{array}{l}\text { Mean } \\
\text { Squar } \\
\mathrm{e}\end{array}$ & $\mathrm{F}$ & Sig. \\
\hline $\begin{array}{l}1 \text { Regressio } \\
n\end{array}$ & 1.262 & 4 & .315 & 41.594 & $.000^{\mathrm{b}}$ \\
\hline Residual & 1.964 & 259 & .008 & & \\
\hline Total & 3.226 & 263 & & & \\
\hline
\end{tabular}

Dengan tingkat signifikansi $5 \%$ dan derajat kebebsan df1 $=4$ dan df2 $=259$ maka $F$ tabel $=2,406496$, diperoleh nilai $\mathrm{F}$ hitung lebih besar dari F Tabel, yaitu (41,594 > 2,460496 disimpulkan bahwa Ha diterima atau hipotesis diterima. sedangkan jika dilihat dari nilai sig hitung adalah $0.000<$ 0.05 maka Ha diterima yang berarti hal ini berarti secara simultan terdapat pengaruh secara signifikan antara Cash conversion cycle, Sales growth, Firm size dan Net working capital terhadap Cash holding pada perusahaan manufaktur yang terdaftar di Bursa Efek Indonesia (BEI) periode 2017-2019.

\section{Pembahasan Pengaruh Masing-Masing Variabel Penelitian : \\ Pengaruh Cash Conversion Cycle (CCC) terhadap Cash Holding ( $\mathrm{CH}$ )}

Hipotesis pertama dikatakan bahwa

Cash Conversion Cycle berpengaruh terhadap Cash Holding. Hal ini sejalan dengan pengujian dalam penelitian ini yang menunjukkan nilai signifikansi 0.000 artinya Cash Conversion Cycle berpengaruh signifikan terhadap Cash Holding sehingga Ha diterima. Perputaran kas yang terfleksi dari cash conversion cycle bisa mempengaruhi saldo kas pada titik tertentu, semakin pendek periode perputaran kas maka akan semakin cepat cash turnover yang diperoleh dan sebaliknya (Marfuah \& Zulhilmi, 2015). Namun menurut penelitian (Liadi \& Suryanawa, 2018) menunjukkan bahwa cash conversion cycle tidak memiliki pengaruh secara signifikan terhadap cash holding.

\section{Pengaruh Sales Growth (SG) terhadap Cash Holding (CH)}

Hipoesis kedua dikatakan bahwa Sales growth berpengaruh terhadap Cash Holding. Hal ini tidak sejalan dengan pengujian dalam penelitian ini yang menunjukkan nilai signifikansi 0.790 artinya Sales growth tidak memiliki pengaruh signifikan terhadap Cash Holding sehingga Ha ditolak atau hipotesis ditolak. Hal ini sejalan dengan penelitian (Panalar \& Ekadjaja, 2020) dalam penelitiannya menyatakan bahwa Sales Growth tidak memiliki pengaruh terhadap Cash Holding karena perusahaan yang bertumbuh pesat biasanya melakukan penjualan namun rata-rata lebih banyak melakukan penjualan kredit sehingga berbentuk piutang bukan kas, sehingga kreditur tidak mempertimbangkan Sales Growth perusahaan. 


\section{Pengaruh Firm Size (FS) terhadap Cash Holding (CH)}

Hipotesis ketiga dikatakan bahwa Firm Size memiliki pengaruh terhadap Cash Holding. Hal ini tidak sejalan dengan pengujian dalam penelitian ini yang menunjukkan nilai signifikansi 0.302 artinya Firm Size tidak berpengaruh signifikan terhadap Cash Holding sehingga Ha ditolak atau hipotesis ditolak. Wijaya dan Bangun (2019), menyatakan bahwa Firm size tidak memiliki pengaruh terhadap Cash Holding yang disebabkan semakin besar perusahaan lebih mudah mengakses pasar modal sehingga perusahaan besar lebih mudah mendapat pendanaan dari luar sehingga mengakibatkan semakin besar kewajiban yang harus dipenuhi perusahaan dari pendanaan luar tersebut sehingga lebih sedikit kas yang dipegang untuk memenuhi kebutuhan operasionalnya lebih sedikit.

\section{Pengaruh Net Working Capital (NWC) terhadap Cash Holding (CH)}

Hipotesis keempat dikatakan bahwa Net Working Capital berpengaruh terhadap Cash Holding. Hal ini sejalan dengan pengujian dalam penelitian ini yang menunjukkan nilai signifikansi 0.000 artinya Net Working Capital memiliki pengaruh signifikan terhadap Cash Holding.

Menurut Nofryanti (2014), Net Working Capital dapat sebagai pengganti terhadap Cash Holding, karena sifat kemudahan dalam likuidasi nya. Penggunaan Net Working Capital untuk membeli aktiva lancar dapat mengurangi saldo kas, sisi lain pada saat penerimaan hasil penjualan akan dapat meningkatkan saldo kas.

\section{Pengaruh Cash Conversion Cycle, Sales Growth, Firm Size dan Net Working Capital terhadap Cash Holding}

Dari hasil penelitian ini secara simultan menunjukkan bahwa Cash Conversion Cycle (CC), Sales Growth (SG), Firm Size (FS) dan Net Working Capital (NWC) berpengaruh terhadap Cash Holding $(\mathrm{CH})$ dengan nilai signifikansi $0.000<0.05$ $(\mathrm{a}=5 \%)$. Hasil koefisien determinasi adjusted $\mathrm{R}$ square sebesar 0.382 yang menujukkan bahwa $38.2 \%$ Cash Holding dipengaruhi oleh variabel Cash Conversion Cycel, Sales Growth, Firm Size dan Net Working Capital, sisanya 61.8\% Cash Holding dipengaruhi oleh variabel lain yang tidak diteliti pada penelitian ini.

\section{Simpulan}

Berdasarkan pada hasil analisis dan pembahasan, maka dapat diambil kesimpulan :

1. Berdasarkan hasil $\mathrm{Uji}-\mathrm{t}$ yang telah dianalisis maka dapat disimpulkan sebagai berikut:

a. Secara parsial ada pengaruh signifikan antara variabel Cash Conversion Cycle (X1) terhadap Cash Holding (Y) pada perusahaan manufaktur yang terdaftar di Bursa Efek Indonesia periode 2017-2019. Hal ini dibuktikan dengan nilai sig sebesar 0.000 , dimana nilai sig < 0.05 yaitu $0.000<0.05$.

b. Secara parsial tidak ada pengaruh signifikan antara variabel Sales Growth (X2) terhadap Cash Holding (Y) pada perusahaan manufaktur yang terdaftar di Bursa Efek Indonesia periode 2017-2019. Hal ini dibuktikan dengan nilai sig sebesar 0.790 , dimana nilai sig > 0.05 yaitu $0.790>0.05$. 
c. Secara parsial tidak ada pengaruh signifikan antara variabel Firm Size (X3) terhadap Cash Holding (Y) pada perusahaan manufaktur yang terdaftar di Bursa Efek Indonesia periode 2017-2019. Hal ini dibuktikan dengan nilai sig sebesar 0.302 , dimana nilai sig $>0.05$ yaitu $0.302>0.05$.

d. Secara parsial ada pengaruh signifikan antara variabel $\mathrm{Net}$ Working Capital (X4) terhadap Cash Holding (Y) pada perusahaan manufaktur yang terdaftar di Bursa Efek Indonesia periode 2017-2019. Hal ini dibuktikan dengan nilai sig sebesar 0.000 , dimana nilai sig < 0.05 yaitu $0.000<0.05$.

2. Berdasarkan hasil Uji F (ANOVA) dalam penelitian ini diperoleh nilai signifikansi sebesar 0.000 dimana nilai signifikansi $<0.05$, yaitu $0.000<$ 0.05 , yang dapat disimpulkan bahwa variabel Cash Conversion Cycle, Sales Growth, Firm Size dan Net Working Capital secara simultan berpengaruh terhadap Cash Holding pada perusahaan manufaktur yang terdaftar di Bursa Efek Indonesia periode 2017-2019.

\section{Saran}

a. Peneliti yang akan datang diharapkan menambah variabel independen lain yang dapat mempengaruhi cash holding perusahaan seperti dividend payment dan investment opportunity, growth opportunity.

b. Peneliti yang akan datang diharapkan bisa menganalisis cash holding pada sektor industri lain yang terdaftar di Bursa Efek Indonesia agar dapat diperbandingkan dalam praktek pengelolaan cash holding.

\section{E. Daftar Pustaka}

Gill, A., \& Shah, C. (2011). Determinants of Corporate Cash Holdings: Evidence from Canada. International Journal of Economics and Finance, 4(1). https://doi.org/10.5539/ijef.v4n1p70

Gomes, M. (2012). The financial determinants of corporate cash holdings: evidence from growing firms.

http://ubibliorum.ubi.pt/handle/10400 $.6 / 2923$

Keown, Arthur J et.all. (2010). Manajemen Keuangan Edisi kesepuluh Jilid 2. Jakarta: Indeks

Liadi, C. C., \& Suryanawa, I. K. (2018). Pengaruh Ukuran Perusahaan, Net Working Capital, Cash Flow, dan Cash Conversion Cycle pada Cash Holding. E-Jurnal Akuntansi, 24, 1474.

https://doi.org/10.24843/eja.2018.v24 i02.p24

Liestyasih, L. P. E., \& Wiagustini, L. P. (2017). Pengaruh Firm Size Dan Growth Opportunity Terhadap Cash Holding Dan Firm Value. E-Jurnal Ekonomi Dan Bisnis Universitas Udayana, $\quad 10, \quad 3607$. https://doi.org/10.24843/eeb.2017.v0 6.i10.p07

Marfuah, M., \& Zulhilmi, A. (2015). Pengaruh Growth Opportunity, Net Working Capital, Cash Conversion Cycle Dan Leverage Terhadap Cash Holding Perusahaan. Optimum: Jurnal Ekonomi Dan Pembangunan, 5(1), 32. https://doi.org/10.12928/optimum.v5i 1.7819

Najema, \& Rusdayanti, A. (2019). Analisis Pengaruh Current Asset, Capital Expenditure, Cash Conversion Cycle, Cash Flow, Leverage, Market To Book Value Dan Net Working 
Capital Terhadap Cash Holdings Pada Sektor Industri Barang Konsumsi Di Bei. Jurnal Sains Manajemen Dan Kewirausahaan, 3(1), 16-26.

Nofryanti. (2014). Pengaruh Net Working Capital, Growth Opportunity Dan Leverage Terhadap Cash Holding (Studi Empiris Pada Perusahaan Property and Real Estate yang Terdaftar di Bursa Efek Indonesia Tahun 2009-2013). Jurnal Ilmiah Akuntansi, 2(4).

Oktamawati, M. (2017). Pengaruh Karakter Eksekutif, Komite Audit, Ukuran Perusahaan, Leverage, Pertumbuhan Penjualan, Dan Profitabilitas Terhadap Tax Avoidance. Jurnal Akuntansi Bisnis, 15(1), 23-40.

https://doi.org/10.24167/JAB.V15I1.1 349

Panalar, P. S., \& Ekadjaja, A. (2020). Pengaruh Sales Growth, Board Size, Dividend Payment, Dan Cash From Operation Terhadap Cash Holding. Jurnal Paradigma Akuntansi, 2(April),667-676.

http://journal.untar.ac.id/index.php/jp a/article/view/7639

Ridha, A., Wahyuni, D., \& Sari, D. M. S. (2019). Analisis Pengaruh Kepemilikan Institusional Dan Profitabilitas Terhadap Cash Holding Dengan Ukuran Perusahaan Sebagai Variabel Moderasi Pada Perusahaan Terindeks Lq45 Di Bursa Efek Indonesia. Jurnal Manajemen Dan Keuangan, 8(2), 135-150. https://doi.org/10.33059/jmk.v8i2.161 8
Riyanto, Bambang. (2010). Dasar-Dasar Pembelanjaan Perusahaan. Yogyakarta : BPFE

Ross, Stephen A et.all. (2015). Essential of Corporate Finance. New York: The McGraw Hill Education

Saputra, H. G. (2015). Determinan Nilai Perusahaan Sektor Property, Real Estate, \& Building Construction Di Bei. Accounting Analysis Journal, 4(2), 1-9. https://doi.org/10.15294/aaj.v4i2.784 8

Sheikh, N. A., Mehmood, K. K., \& Kamal, M. (2018). Determinants of Corporate Cash Holdings: Evidence from MNCs in Pakistan. Review of Economics and Development Studies, 4(1), 71-78. https://doi.org/10.26710/reads.v4i1.2 82

Wijaya, S. H., \& Bangun, N. (2019). Pengaruh Arus Kas, Leverage, Dan Ukuran Perusahaan Terhadap Cash Holding. Jurnal Multiparadigma Akuntansi, I(2), 495-504. 